\title{
Effects of Nitrate and Phosphate Limitation on Cyclostat Growth of Two Freshwater Diatoms
}

\author{
By IVAN J. GOTHAM* AND G-YULL RHEE \\ Environmental Health Institute, Division of Laboratories and Research, New York State \\ Department of Health, Albany, New York 12201, U.S.A.
}

(Received 24 February 1981; revised 3 June 1981)

\begin{abstract}
The effects of $\mathrm{N}$ and $\mathrm{P}$ limitation on cell division and on cellular contents of limiting and non-limiting nutrients were examined in cyclostat cultures of the freshwater diatoms Asterionella formosa and Fragilaria crotonensis. Nutrient-limited cell cycles of both species were readily entrained by a $14 \mathrm{~h} / 10 \mathrm{~h}$ light/dark cycle. In $F$. crotonensis, the maxima relative to the onset of the light phase of the photocycle occurred at approximately -1 to $+1 \mathrm{~h}$ for cell division, +11 to $13 \mathrm{~h}$ for cell $\mathrm{N}$, and +21 to $23 \mathrm{~h}$ for cell $\mathrm{P}$. In $A$. formosa the maxima occurred at approximately +3 to $10 \mathrm{~h}$ for cell division and +2 to $4 \mathrm{~h}$ for cell $\mathrm{N}$ and cell $\mathrm{P}$. Changes in culture dilution rate (integrated growth) and in the type of nutrient limiting growth did not significantly alter these times for either species. The cell-number oscillations can be explained by a simple exponential function for the instantaneous population growth rate, which occurs after a single modal transition time $\tau$, which is characteristic for each species. The consistency of phase relations between $\mathbf{N}$ and $\mathbf{P}$ limitations and culture dilution rates suggests that the temporal organization for events within the cell cycle of each organism is independent of the nutrient-limited status of the cell populations.
\end{abstract}

\section{INTRODUCTION}

The course of vegetative reproduction in planktonic algae, as with other cells, is the cell cycle. It is well known that events which occur within the cell cycle of eukaryotic algae are readily entrained by $24 \mathrm{~h}$ light/dark (L/D) cycles (Chisholm, 1981; Chisholm et al., 1981; Rhee et al., 1981). The actual mechanism(s) responsible for the timing of the events relative to the light cycle is poorly understood. Conceivably the timing reflects a compromise between the physiological requirements of the cell, an endogenous biochemical clock, and the stochastic processes governing the distribution of generation times that are inherent in the population (see Edmunds \& Cirillo, 1974; Smith \& Martin, 1974; Klevecz, 1976; Chisholm \& Costello, 1980).

The effects of nutrient limitation on the events that occur during the cell cycle of planktonic algae can be readily studied in nutrient-limited cyclostat cultures (Chisholm et al., 1975; Rhee et al., 1981). Extensive experimental and theoretical studies of nutrient-limited cyclostat growth have been conducted with a single 'ideal' species, Euglena gracilis (see Frisch \& Gotham, 1977, 1979). However, there have been few attempts to examine the effects of nutrient limitation on cyclostat growth of species that are representative of freshwater communities. The purpose of the present study was to examine the effects of $\mathrm{N}$ - and P-limited growth on the phase relationships of maxima in cell division and in cell contents of limiting and non-limiting nutrients for two freshwater diatoms, Asterionella formosa and Fragilaria crotonensis. 


\section{METHODS}

Axenic cultures of $A$. formosa and F. crotonensis were obtained from Dr S. S. Kilham \& Dr D. Tilman respectively. Cell cultures were grown in defined inorganic media modified from Guillard \& Lorenzen (1972). In $\mathrm{P}$-limited growth medium the $\mathrm{P}$ concentration was reduced to $1 \mu \mathrm{M}$; the $\mathrm{N}$ concentration was $100 \mu \mathrm{M}\left(\right.$ as $\left.\mathrm{KNO}_{3}\right)$ and the Tris buffer concentration was $2 \mu \mathrm{M}$. In the $\mathrm{N}$-limited experiments with $F$. crotonensis, the medium $\mathrm{N}$ concentration was $21 \mu \mathrm{M}$ (as $\mathrm{KNO}_{3}$ ); the $\mathrm{P}$ concentration was $10 \mu \mathrm{M}$ and the Tris buffer concentration was $2 \mu \mathrm{M}$. The $\mathrm{N}$-limited growth medium for $F$. crotonensis was also supplemented with $\mathrm{KCl}(90 \mu \mathrm{M})$ to compensate for the decreased $\mathrm{K}$ concentration that resulted from the low $\mathrm{KNO}_{3}$ concentration. The $\mathrm{N}$ concentration was the same for the $\mathrm{N}$-limited experiments with $A$. formosa; however the Tris was replaced with a phosphate buffer containing 200 $\mu \mathrm{M}-\mathrm{KH}_{2} \mathrm{PO}_{4}$ and $300 \mu \mathrm{M}-\mathrm{K}_{2} \mathrm{HPO}_{4}$.

Unless otherwise indicated, the design of continuous culture vessels, culture conditions and techniques were the same as described by Rhee (1978) and Rhee \& Gotham $(1981 a, b)$. The continuous culture populations were maintained on a $14 \mathrm{~h} / 10 \mathrm{~h} \mathrm{~L} / \mathrm{D}$ cycle with a daylight irradiance of about $20 \mathrm{~W} \mathrm{~m}^{-2}$, with lights on at 0800 and off at 2200; this interval was designated the 'subjective day'. The temperature of the cultures remained constant at 19 $\pm 0.5^{\circ} \mathrm{C}$ and the $\mathrm{pH}$ at $7.4 \pm 0.2$.

Continuous cultures were allowed to run to a steady, periodic state before $24 \mathrm{~h}$ sampling protocols were initiated. A culture was judged to be in steady, periodic state when cell concentrations at 0900 showed no increasing or decreasing trends and varied by no more than $\pm 5 \%$ for three consecutive photocycles. At the initiation of the $24 \mathrm{~h}$ sampling, the medium outflow line (the flow through which had been maintained by gravity) was removed aseptically and replaced with $5 \mathrm{~cm}$ of sterile silicone rubber tubing, which was attached to a Teflon-lined continuous piston pump. The outflow port of the pump was attached to $5 \mathrm{~cm}$ of acid-washed glass tubing that was positioned over a refrigerated fraction collector. Outflow samples were collected at $2 \mathrm{~h}$ intervals in acid-washed glass test tubes. Samples for cell-number determinations were collected in tubes containing $0.05 \mathrm{ml}$ Lugol's solution for three or four sequential photocycles at $0^{\circ} \mathrm{C}$. Samples obtained for total cell $\mathrm{P}$ or residual $\mathrm{N}$ and $\mathrm{P}$ determinations were collected during subsequent photocycles at $0^{\circ} \mathrm{C}$ without preservative. Control experiments showed no significant changes in these variables when samples were maintained at this temperature and preserved (see below) within 12 to $15 \mathrm{~h}$. The cell numbers in these samples were determined after adding $0.05 \mathrm{ml}$ of Lugol's solution to a $1.0 \mathrm{ml}$ subsample removed from each collection tube.

Samples for total cell $\mathrm{P}$ determinations were concentrated by centrifugation and preserved at $-40{ }^{\circ} \mathrm{C}$ for later analysis, as described by Rhee \& Gotham $(1981 a, b)$. Cell suspensions for residual $\mathrm{N}$ and $\mathrm{P}$ determinations were gently filtered through $0.45 \mu \mathrm{m}$ membrane filters which had been boiled and prewashed in distilled water. The filtrate and media reservoir samples were preserved at $-40^{\circ} \mathrm{C}$ for later analysis of dissolved $\mathrm{N}$ and $\mathrm{P}$, as described by Rhee (1978) and Rhee \& Gotham $(1981 a, b)$. Cell contents of $\mathrm{N}$ and $\mathrm{P}$ at a given time of day were determined as the difference between reservoir and residual concentrations, divided by the cell number. For $\mathrm{N}$-limited $A$. formosa, however, total cell $\mathrm{P}$ determinations were necessitated by the high reservoir concentration of $\mathrm{P}$ in the buffers.

Cell numbers were determined in a haemocytometer. The cell suspensions of $F$. crotonensis were sonicated for $15 \mathrm{~s}$ at a setting of 50 with a Biosonik IIa cell sonicator (Bronwill Scientific, Rochester, N.Y.) equipped with a needle-tip probe. This procedure facilitated counting of this species by breaking up long chains of frustule filaments without decreasing the absolute cell counts. Owing to the inherent variation in the counting technique used in this study, it was not possible to examine the oscillations in cell number data with a Fourier time-series analysis (see Chisholm \& Costello, 1980). Instead, the cell number points obtained for corresponding times of the three to four photocycles examined were superimposed and averaged.

In these periodic continuous cultures, i.e. cultures maintained on $\mathrm{L} / \mathrm{D}$ cycles, the instantaneous population growth rate $\mu(t)$ is not instantaneously equal to the culture dilution rate $D$, as in steady-state chemostats. Instead, only the period-averaged growth rate $\langle\mu\rangle_{T}$ is equal to $D$ (Frisch \& Gotham, 1977, 1979):

$$
\langle\mu\rangle_{t}=D=(1 / T) \int_{0}^{T} \mu(t) \mathrm{d} t
$$

where $\langle\ldots\rangle_{T}$ denotes period average and $T$ is the period length ( $24 \mathrm{~h}$ in the case of daily cell-division rhythms). In this study the term integrated growth, $D T$ (equation 1) will be used, rather than chemostat dilution rate. Integrated growth and chemostat dilution rate are numerically but not dimensionally equivalent. Integrated growth is dimensionless, whereas chemostat dilution rate is in units of $\mathrm{d}^{-1}$.

Cell number concentration $(X)$ was chosen as the primary variable to express growth rate because: (1) its use is entirely consistent with cyclostat, or continuous culture theory (Frisch \& Gotham, 1977, 1979); (2) its use as a measure of population biomass provides an excellent description of $\mathrm{N}$ - and P-limited continuous culture growth of the two test species as well as many other species (Gotham \& Rhee, 1981 $a, b$; Rhee et al., 1981); and (3) its value is appropriate for determining population growth rates (cell division). 


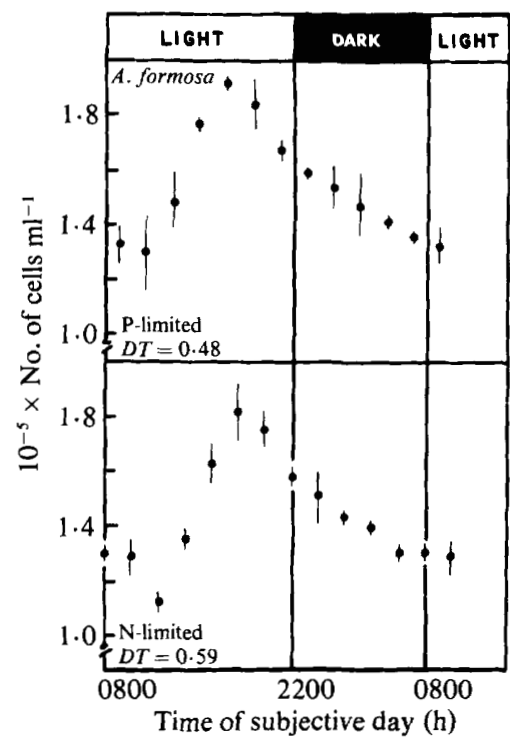

Fig. 1

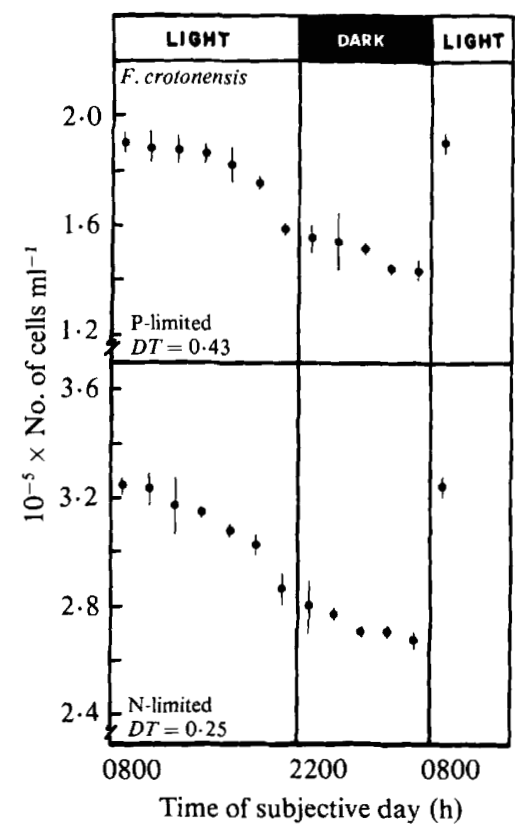

Fig. 2

Fig. 1. Cell-number oscillations averaged over three photocycles for $\mathrm{N}$ - and $\mathrm{P}$-limited cyclostat cultures of $A$. formosa. Cultures were maintained at $19^{\circ} \mathrm{C}$ on a $14 \mathrm{~h} / 10 \mathrm{~h} \mathrm{~L} / \mathrm{D}$ cycle. $D T$ is the integrated growth of the culture population. The error bars represent the standard errors of the means.

Fig. 2. Cell-number oscillations averaged over four photocycles for $\mathrm{N}$ - and P-limited cyclostat cultures of $F$. crotonensis. Cultures were maintained at $19^{\circ} \mathrm{C}$ on a $14 \mathrm{~h} / 10 \mathrm{~h} \mathrm{~L} / \mathrm{D}$ cycle. $D T$ is the integrated growth of the culture population. The error bars represent the standard errors of the means.

\section{RESULTSAND DISCUSSION}

\section{Oscillations in cell number}

Cell division (cytokinesis), as indicated by increases in cell concentration, $X(t)$, showed strongly rhythmic behaviour in both $A$. formosa and $F$. crotonensis when either $\mathrm{N}$ or $\mathrm{P}$ limited integrated growth $(D T)$ of the culture population (Figs 1 and 2). In continuous culture the rate of change in cell concentration with time $(\mathrm{d} X / \mathrm{d} t)$ is given by:

$$
\mathrm{d} \ln X / \mathrm{d} t=\mu(t)-D
$$

where $\mu(t)$ is the instantaneous population growth rate and $D$ is the dilution rate of the culture, which is expressed in the same units of time as $\mu(t)$. An increase in cell numbers with time during the photocycle, i.e. a positive $\operatorname{dln} X / \mathrm{d} t$, indicates that $\mu(t)>D$. Thus the time interval during which $\mathrm{d} \ln X / \mathrm{d} t$ is positive is likely to contain the time at which $\mu(t)$ is at a maximum.

The phase relationship of the time interval for positive $\mathrm{d} X / \mathrm{d} t$ to the subjective dawn $(0800)$ is clearly different for each species. In $F$. crotonensis a positive $\mathrm{d} X / \mathrm{d} t$ occurs over a $2 \mathrm{~h}$ interval from 0700 to 0900 (Fig. 2). In $A$. formosa the interval of positive $\mathrm{d} X / \mathrm{d} t$ is longer and later, from about 1130 to 1800 (Fig. 1). The phasing of this increase in $X(t)$ appears to be little affected by integrated growth of the culture population (Figs 1 and 2).

The results obtained in the present study with $A$. formosa and $F$. crotonensis are in agreement with those obtained for P-limited cyclostat growth of Euglena gracilis. There too the integrated growth of the species does not affect the phasing of cell division (Chisholm et 


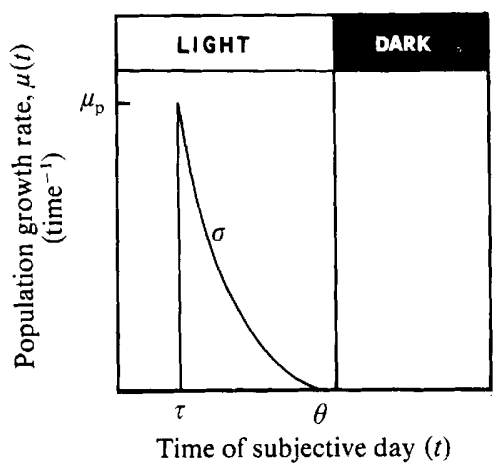

Fig. 3. Simplified exponential function for the instantaneous population growth rate $\mu(t)$ used to account for the oscillations in cell number in nutrient-limited cyclostat cultures. $\tau$ is the time of a single maximum in the distribution of $\mu(t)$ over the length of the photoperiod ( $24 \mathrm{~h}) ; \sigma$ is the time constant for the decay of $\mu(t) ; \mu_{\mathrm{p}}$ is the maximum population growth rate for the photoperiod; $\theta$ is the time at which $\mu(t)=0$.

al., 1975; Gotham, 1977; Frisch \& Gotham, 1979; I. J. Gotham, unpublished data). In Nand P-depleted, phased cultures of Candida utilis the timing of initiation of cell division also remains virtually unchanged, although when carbon sources are depleted the onset of division in this yeast occurs much earlier in the phased culture cycle (Glattli \& Dawson, 1974). In the fast-growing marine diatom Thalassiosira fluviatilis, Chisholm \& Costello (1980) have observed an $8 \mathrm{~h}$ phase shift in the maximum for cell division between nutrient-unlimited and P-limited cyclostat cultures. In the present study, however, oscillations in cell number density were monitored only when there was no increasing or decreasing trend in $X(t)$ between photoperiods. In any case, in cultures with average generation times of $>1 \mathrm{~d}$, it would seem likely that in the diatoms examined here the type of limiting nutrient and the integrated growth of the culture population affect only the frequency of cells entering division about a modal time $(\tau)$, rather than the phase relation of $\tau$ to the L/D cycle (e.g. Gotham \& Frisch, 1981). The effect of the type of limiting nutrient on $\tau$ is in contrast to the observed effects of environmental factors (such as temperature, irradiance, and the L/D ratio of photocycles) (see Rhee et al., 1981).

Owing to the mathematical complexity involved in the theory of cyclostat growth (see Frisch \& Gotham, 1977, 1979) it would be advantageous to determine if the oscillations in cell number observed here can be described by a simplified form for $\mu(t)$. As a simple approximation it was assumed that $\mu(t)$ takes the form of an exponential function that decays from a maximum value $\mu_{\mathrm{p}}$ at time $\tau$ to 0 at time $\theta$ (Fig. 3). In this form, for $\tau \leq t \leq \theta$ and $\mu(t)$ $=\mu(t+T)$,

$$
\mu(t)=\mu_{\mathrm{p}}\{2 \exp [(\tau-t) / \sigma]-1\}
$$

where $\sigma$, the time constant for the decay, is equal to $(\theta-\tau) / \ln 2$ (assuming that at $t \rightarrow \infty, \mu(t)$ $\left.=-\mu_{\mathrm{p}}\right)$. For practical purposes it is taken that for $0 \leq t<\tau$ and for $\theta<t \leq T, \mu(t)=0$. From equation (1), then, we have the condition

$$
D T=\int_{0}^{T} \mu(t) \mathrm{d} t=\mu_{\mathrm{p}}(\theta-\tau) /[(1 / \ln 2)-1]
$$

which can be used to solve for any one of three parameters at a given value of $D T$.

The relative cell number at any time during the $\mathrm{L} / \mathrm{D}$ cycle is given by the function

$$
X(t) / X_{0}=\exp \left[\int_{0}^{t} \mu(t) \mathrm{d} t-D t\right]
$$


Table 1. Values obtained from fit of cell-number oscillations to a simplified form of instantaneous population growth rate, $\mu(t)$

The parameter $\mu_{\mathrm{p}}$ is the peak of the oscillation in $\mu(t), \tau$ is the time at which the peak occurs, and $\theta$ is the time at which $\mu(t)$ decays to zero.

\begin{tabular}{|c|c|c|c|c|c|c|c|}
\hline Species & $\begin{array}{l}\text { Limiting } \\
\text { nutrient }\end{array}$ & $D T$ & $\begin{array}{c}\mu_{\mathrm{p}} \\
\left(\mathrm{h}^{-1}\right)\end{array}$ & $\begin{array}{c}\text { Time of } \\
X_{0}{ }^{*}\end{array}$ & $\begin{array}{l}\tau^{\dagger} \\
(\mathrm{h})\end{array}$ & $\begin{array}{l}\theta \dagger \\
(\mathrm{h})\end{array}$ & Variance ratio $\ddagger$ \\
\hline A. formosa & $\mathbf{P}$ & 0.48 & 0.205 & 1100 & $1 \cdot 10$ & $6 \cdot 40$ & $F_{(1,9)}=209 \cdot 3$ \\
\hline A. formosa & $\mathrm{N}$ & 0.59 & 0.235 & 1200 & 0.87 & $6 \cdot 55$ & $F_{(1,9)}=187.0$ \\
\hline F. crotonensis & $\mathbf{P}$ & 0.43 & 0.360 & 0700 & 0.50 & $3 \cdot 20$ & $F_{(1,9)}=165 \cdot 0$ \\
\hline F. crotonensis & $\mathrm{N}$ & 0.25 & 0.195 & 0700 & $0 \cdot 30$ & $3 \cdot 20$ & $F_{(1,9)}=144.9$ \\
\hline
\end{tabular}

where $X(t)=X(t+T)$ and $X_{0}=X$ at $t=0$. For example, $X_{0}$ is the cell number at the trough of the oscillation in $X(t)$.

Since we were interested in describing the observed patterns of $X(t)$, rather than determining experimental values for $\mu(t)$, the parameters $\tau$ and $\theta$ for the integral of equation (3) were used to generate predicted values of $X(t) / X_{0}$. The fit of equation (3) to the data was accomplished by varying $\tau$ and $\theta$ to minimize the sum of squared errors for predicted minus observed $X(t) / X_{0}$ over the photocycle. Analysis of variance was used to evaluate the goodness of fit. The values and variance ratios obtained by this procedure are presented in Table 1.

For integrated growth under all four conditions examined, the variance ratio was highly significant $(P<0.001)$. Thus it may be concluded that the simple form for $\mu(t)$ as given in equation (3) is adequate to describe the observed oscillations in relative cell number in both species. This result does not exclude the possibility of multimodal peaks in $\mu(t)$ for these species (Chisholm \& Costello, 1980). We have simply shown that whatever microscopic form $\mu(t)$ has in actuality, it can be approximated on the average by a simple first-order decay during a specified interval $(\tau-\theta)$ of the photocycle.

A simple mechanistic explanation for the basis of the form of $\mu(t)$ examined here would be to hypothesize a single, modal transition point $\tau$ during the $\mathrm{L} / \mathrm{D}$ cycle, which corresponds to a transition point for division in the phased cell cycle (Smith \& Martin, 1974; Frisch \& Gotham, 1979; Gotham \& Frisch, 1981).

Conceivably this modal time could represent the minimum amount of exposure time to light (or dark) during the photocycle that is required by mature cells in order to undergo cell division (e.g. Chisholm \& Costello, 1980). Thus the cells within the population that are physiologically committed to division, once having passed this point in time during the $L / D$ cycle, undergo division at random times during the interval between $\tau$ and $\theta$ (Fig. 3).

\section{Oscillations in cellular nutrient content}

Cellular contents of $\mathrm{N}$ and $\mathrm{P}$ in both test species showed $24 \mathrm{~h}$ rhythmicity, regardless of which nutrient limited the integrated growth of the culture population (Figs 4 and 5). The phase relationships of cell $\mathrm{N}$ and $\mathrm{P}$ to $\tau$ and to the subjective dawn also remained essentially constant in both species during both $\mathrm{N}$ - and P-limited growth. In $F$. crotonensis the maxima for cell $\mathrm{P}$ occurred within 1 to $3 \mathrm{~h}$ before the subjective dawn, whereas cell $\mathrm{N}$ reached a maximum plateau at 11 to $13 \mathrm{~h}$ after the subjective dawn. In $A$. formosa maximum cell $\mathrm{P}$ occurred in phase with maximum cell $\mathrm{N}$ at approximately 2 to $4 \mathrm{~h}$ after the subjective dawn. In Euglena gracilis the phase relation of maximum $\mathrm{P}$ uptake to both the subjective dawn and $\tau$ remains constant and independent of integrated growth of the culture (Gotham, 1977 and 


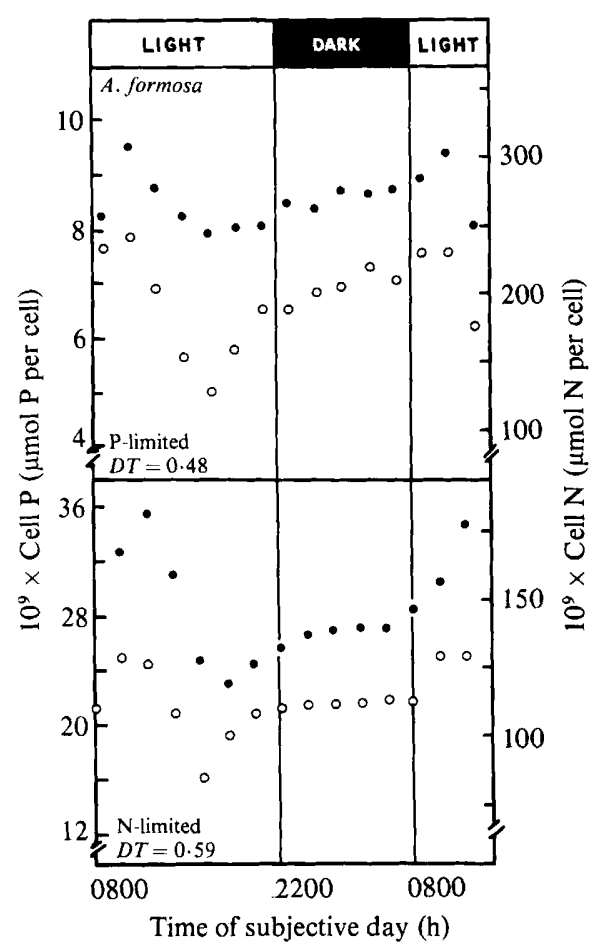

Fig. 4

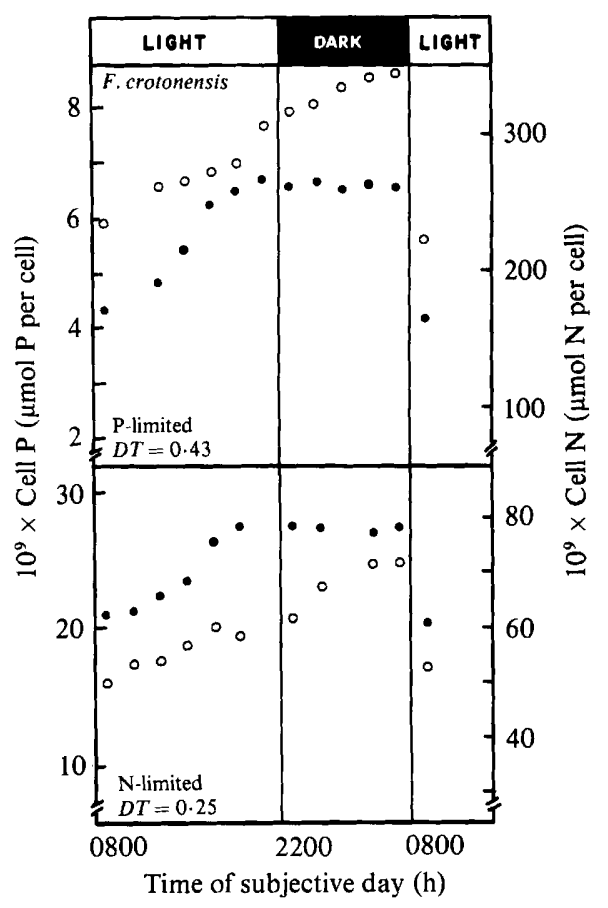

Fig. 5

Fig. 4. Oscillations in cell $N(O)$ and cell $P(O)$ in nitrate-limited and in phosphate-limited cyclostat cultures of $A$. formosa. Data were obtained from a single photocycle. $D T$ is the integrated growth of the culture population.

Fig. 5. Oscillations in cell $N(O)$ and cell $P(O)$ in nitrate-limited and in phosphate-limited cyclostat cultures of $F$. crotonensis. Data were obtained from a single photocycle. $D T$ is the integrated growth of the culture population.

unpublished observations). The consistency of phase relationships of cell nutrient content and cell division to the L/D cycle would therefore seem to indicate that the temporal order of events within the cell-growth and DNA-division cycles of these organisms is independent of growth limitation by either nitrate- $\mathrm{N}$ or phosphate-P.

This oscillatory behaviour of cell $\mathrm{N}$ and $\mathrm{P}$ in these species can presumably be extended to their nitrate and phosphate uptake rates. Daily rhythms in nutrient uptake appear to be common among planktonic algae. There also appears to be considerable interspecific diversity with respect to phase relationships of uptake maxima to $24 \mathrm{~h} \mathrm{~L} / \mathrm{D}$ cycles (Rhee $e t$ $a l ., 1981)$. It is conceivable that this diversity in temporal patterns for uptake and cell division could serve to enhance stability within phytoplankton assemblages by promoting the coexistence of species sharing a common limiting nutrient. Coexistence would presumably occur if consumption of that nutrient could be partitioned in time during the $\mathrm{L} / \mathrm{D}$ cycle via rhythmicities in the uptake rate for that nutrient (Williams, 1971; Stross \& Pemrick, 1974; Chisholm et al., 1978; Rhee et al., 1981).

In summary, we have shown that in two freshwater diatoms the specific phase relations of cell division and cell $\mathrm{N}$ and $\mathrm{P}$ to the $\mathrm{L} / \mathrm{D}$ cycle remain virtually unaffected when either nutrient limits the integrated growth of the cyclostat population. The phasing of cellular nutrients and $\mu(t)$ in each species also appears to be scarcely affected by the integrated growth of the cell culture. The instantaneous population growth rate responsible for the daily oscillations in cell number can be approximated by a simple exponential decay function. 
This work was supported by National Science Foundation grant DEB 75-19519 and Environmental Protection Agency grant R-804689 to G-Y.R. We thank Dr G. W. Fuhs for his helpful comments on the manuscript and Mrs E. Kusel for technical assistance.

\section{REFERENCES}

Chisholm, S. W. (1981). Temporal patterns of cell division in unicellular algae. In Physiological Phytoplankton Ecology, (in the Press). Edited by T. Platt. Lapari, Sicily: NATO Advanced Study Institute.

Chisholm, S. W. \& Costello, J. C. (1980). Influence of environmental factors and population composition on the timing of cell division in Thalassiosira fluviatilis (Bacillariophyceae) grown on light/dark cycles. Journal of Phycology 16, 375-383.

Chisholm, S. W., Stross, R. G. \& Nobbs, P. A. (1975). Light/dark phased cell division in Euglena gracilis (Z) (Euglenophyceae), in $\mathrm{PO}_{4}$ limited cultures. Journal of Phycology 11, 367-373.

Chisholm, S. W., Azam, F. \& Eppley, R. W. (1978). Silicic acid incorporation in marine diatoms on light/dark cycles: use as an assay for phased cell division. Limnology and Oceanography 23, 518529.

Chisholm, S. W., Morel, F. M. M. \& Slocum, W. S. (1981). The phasing and distribution of cell division cycles in marine diatoms. Brookhaven Symposia in Biology 31, 281-300.

Edmunds, L. J., JR \& Cirillo, V. P. (1974). On the interplay among cell cycle, biological clock and membrane transport control systems. International Journal of Chronobiology 2, 233-264.

FrISCH, H. K. \& GothaM, I. J. (1977). On periodic cyclostat populations. Journal of Theoretical Bio$\log y$ 66, 665-678.

FrISCh, H. L. \& Gotham, I. J. (1979). A simple model for periodic cyclostat growth of algae. Journal of Mathematical Biology 7, 149-169.

Glattli, H. \& Dawson, P. S. S. (1974). Incorporation of phosphorus into phased cells of Candida utilis using ${ }^{32} \mathrm{P}$ and ${ }^{33} \mathrm{P}$. Archives of Microbiology 95, 237-254.

Gotham, I. J. (1977). Nutrient limited cyclostat growth: a theoretical and physiological analysis. Ph.D. thesis, State University of New York at Albany, U.S.A.

GothaM, I. J. \& FrisCH, H. L. (1981). A simple model for cell volume and developmental compartments in nutrient-limited cyclostat cultures of algae. Journal of Theoretical Biology 92, 435-467.

Gotham, I. J. \& RhEE, G-Y. (1981 a). Comparative kinetic studies of phosphate-limited growth and phosphate uptake in phytoplankton in continuous culture. Journal of Phycology 17, 257-265.

Gotham, I. J. \& RheE, G-Y. (1981b). Comparative kinetic studies of nitrate-limited growth and nitrate uptake in phytoplankton in continuous culture. Journal of Phycology 17, 309-314.

Guillard, R. R. L. \& LORENZEN, C. J. (1972). Yellow-green algae with chlorophyllide $c$. Journal of Phycology 8, 10-14.

KLEVECZ, R. R. (1976). Quantized generation time in mammalian cells as an expression of the cellular clock. Proceedings of the National Academy of Sciences of the United States of America 73, 4012-4016.

RHEE, G-Y. (1978). Effects of $N: P$ atomic ratios and nitrate limitation on algal growth, cell composition, and nitrate uptake. Limnology and Oceanography 23, $10-25$.

RHEE, G-Y. \& GothaM, I. J. (1981a). The effect of environmental factors on phytoplankton growth: temperature and the interactions of temperature with nutrient limitation. Limnology and Oceanography 26, 635-648.

RHEE, G-Y. \& GothaM, I. J. (1981 b). The effect of environmental factors on phytoplankton growth: light and the interactions of light with nitrate limitation. Limnology and Oceanography 26, 649659.

Rhee, G-Y., Gotham, I. J. \& Chisholm, S. W. (1981). Use of cyclostat cultures to study phytoplankton ecology. In Continuous Culture of Cells, vol. 2, pp. 159-186. Edited by P. H. Calcott. Ohio: CRC Press.

SMITH, J. A. \& MARTIN, L. (1974). Regulation of cell proliferation. In Cell Cycle Controls, pp. 43-60. Edited by G. M. Padilla, I. L. Cameron \& A. Zimmerman. New York: Academic Press.

Stross, G. G. \& Pemrick, S. M. (1974). Nutrient uptake kinetics in phytoplankton: a basis for niche separation. Journal of Phycology 10, 164-169.

Williams, F. M. (1971). Dynamics of microbial populations. In Systems Analysis and Simulation in Ecology, vol. 1, pp. 197-267. Edited by B. C. Patten. New York: Academic Press. 